\title{
Az Önkritikusság és Önmegerósítés Skála hazai validálása
}

\author{
BOROSTYÁNKÖI ZSÓFIA - TAKÁCS SZABOLCS - \\ SZABÓ-BARTHA ANETT*
}

Károli Gáspár Református Egyetem, BTK, Pszichológiai Intézet, Budapest

(Beérkezett: 2019. november 11.; elfogadva: 2021. január 12.)

\begin{abstract}
Elméleti háttér: A Self-Criticizing/Attacking and Self-Reassuring Scale (Önkritikusság és Önmegerősítés Skála) magyar változatának köszönhetően az önkritikusság jelensége Magyarországon is mérhetővé vált. Cél: Jelen vizsgálat során bemutatásra kerül az Önkritikusság és Önmegerősítés Skála magyar mintán történő alkalmazhatósága, és az önegyüttérzéstől való félelem mellett a depresszióval, valamint az élettel való elégedettséggel vizsgált öszszefüggése. Módszerek: A kutatásban összesen 434 fő vett részt: 107 férfi és 327 nő, átlagéletkoruk 30,2 (SD = 12,15) év. Eredmények: A feltáró faktoranalízis az Önkritikusság és Önmegerósítés Skála (FSCRS-HU) esetén az eredetihez hasonló háromfaktoros struktúrát jelzett: a magyar mintán is megjelentek az alkalmatlan én (inadequate self), a megerősitett én (reassured self) és a gyülölt én (hated self) dimenziói. Ezt a struktúrát a konfirmatív faktoranalízis is megerősítette (RMSEA $=0,056 ; \mathrm{CFI}=0,945$ ) és az alskálák belső megbízhatósága megfelelőnek bizonyult (Cronbach- $\alpha=0,9 ; 0,87,0,83$, sorrendben). Az FSCRS-HU mind a depresszióval $(r=0,62-0,68 ; p<0,01)$, mind az önegyüttérzéstől való félelemmel $(r=0,65$ $-0,68 ; p=0,01)$ és az élettel való elégedettséggel $(r=[-0,51]-[-0,52] ; p=0,01)$ is szignifikáns, közepes erősségú együttjárást mutatott. Az életkor gyenge, az alkalmatlan én esetében pedig közepes mértékú szignifikáns hatása mindhárom alskálánál megjelent. A nemek közt azonban egyedül az alkalmatlan én esetén volt szignifikáns különbség $(Z=-2,109 ; p=$ 0,040; rang Cohen- $d=-0,229)$. Következtetések: Összességében az Önkritikusság és Önmegerősítés Skála megbízható és érvényes mérőeszköznek bizonyult hazai mintán is.
\end{abstract}

Kulcsszavak: Önkritikusság és Önmegerősítés Skála (FSCRS-HU), önkritikusság, önmegerősítés, depresszió, önegyüttérzéstől való félelem, élettel való elégedettség, validitás

\section{Bevezetés}

Az életünk természetes velejárója, hogy időnként nehézségekbe ütközünk, hibázunk, kudarcot vallunk. Ezekre a helyzetekre változatosan reagálhatunk: elnézően, megértően, esetlegesen felmentve magunkat az adott helyzetben, míg máskor mi magunk válunk önmagunk legszigorúbb kritikusává.

\footnotetext{
* Levelező szerző: Dr. Szabó-Bartha Anett, Károli Gáspár Református Egyetem, Pszichológiai Intézet, Személyiség- és Egészségpszichológiai Tanszék, 1037 Budapest, Bécsi út 324. V. ép. E-mail: bartha.anett@kre.hu
} 
Sőt, míg másokkal szemben időnként könnyebben visszafogjuk az esetleges bántó megjegyzéseinket, saját magunkkal már nem vagyunk ennyire kedvesek, mivel nincs, ami gátat szabjon a kritikus gondolatainknak (Gilbert, 2009).

Az önkritikusság egy komplex jelenség, amiről elmondható, hogy napjainkban a nyugati kultúrák egyik legelterjedtebb problémái közé tartozik. Szégyennel párosulva pedig egyike a leginkább romboló belsó folyamatoknak, és az önegyüttérzés szöges ellentétét képviseli, amelyek kapcsolatára a későbbiekben részletesen kitérünk. Alááshatja az ember pszichológiai jóllétét, megelégedettségét, sőt boldogságát is - így jelentősége egyáltalán nem elhanyagolható (Gilbert, 2009). Hazánkban eddig még nem állt rendelkezésre megfelelő méróeszköz a jelenség mérésére. Vizsgálatunkban a Gilbert, Clarke, Hempel, Miles és Irons (2004) által kidolgozott Self-Criticizing/ Attacking and Self-Reassuring Scale (magyarul: Önkritikusság és Önmegerősítés Skála) magyar mintán történő validálását túztük ki célul.

\section{Elméleti áttekintés: Az önkritikusság}

Gilbert, McEwan, Gibbons, Chotai, Duarte és Matos (2012) meghatározása alapján az önkritikusság egy olyan belső folyamat, amely beszúkíti, lezárja az olyan csatornákat az egyénen belül, amelyek saját érzelmeink, érzelmi világunk, önmagunk felfedezéséért felelősek. Így e során azok a képességeink korlátozódnak, amelyek segíthetnek abban, hogy nyitottak legyünk és felfedezzük a saját érzéseinket, és azok elfogadása révén biztonságban érezzük magunkat (Gilbert és mtsai, 2012).

Az erősen önkritikus emberek nem merik leengedni a falakat maguk körül. Gyengeségnek tartják azt, és nehezükre esik a mások (vagy önmaguk) felől érkező melegség és kedvesség megtapasztalása. Az önmagukkal való együttérzéstől (ún. önegyüttérzéstól) egyenesen félnek, s kifejezetten ijesztőek lehetnek számukra a pozitív érzelmek, többek között a boldogság megélése is (Gilbert, Baldwin, Irons, Baccus, \& Palmer, 2006; Gilbert és mtsai, 2012; Gilbert, McEwan, Matos, \& Rivis, 2011; Gilbert \& Procter, 2006).

Az önegyüttérzés nem más, mint egy önmagunkkal szembeni kedves, megértő, szemlélő viszonyulási mód, amely a pszichés jóllétünk szempontjából is meghatározó tényező (Neff, 2011). Három összetevője a következő: (a) az önmagunk iránt érzett kedvesség, szemben az önbírálattal; (b) a közös emberi természet megtapasztalása, szemben az izolációval; (c) és végül a tudatos jelenlét (azaz a saját belső élményeink nyitott, ítélkezés- és reaktivitásmentes észlelése), szemben az azokkal való túlzott azonosulással (Neff, 2011). Magas önkritikusság esetében ezek megtapasztalása nehézzé 
válik az egyén számára, és hozzájárul a pszichológiai jóllét csökkenéséhez, valamint a szorongás és a depresszió szintjének megemelkedéséhez (Neff \& McGehee, 2010).

Az önkritikus beállítódás összekapcsolódhat azzal az aggodalommal is, hogy vajon mit gondolnak rólunk mások, milyennek túnhetünk a szemükben; félünk, hogy lenéznek és visszautasítanak minket; emellett kritikát vagy elutasítást feltételezünk az irányukból. Ekkor a külső és a belső világunk egyaránt kritikusnak és fenyegetőnek látszik: sehol sem érezzük magunkat biztonságban, sehol sem tudunk igazán megnyugodni (Gilbert, 2009). Mindez kapcsolatban állhat az önkritika kialakulásának hátterével. Hiszen az önmagunkhoz való viszonyulás és bánásmód nagyban függ a koragyermekkori tapasztalatoktól. Az önkritikusság legnyilvánvalóbb gyökerei a múltban keresendők, és legtöbbször a szülői bánásmóddal vannak öszszefüggésben. Az erősen önkritikus emberek szüleinél gyakran találtak kritikus, elhanyagoló és elutasító viszonyulást a gyermekükkel szemben (Gilbert, 2009; Gilbert és mtsai, 2006). Azok a személyek tehát, akik magas önkritikával rendelkeznek, valószínúleg nem tapasztalták meg gyermekkorukban a biztonságos kötődést, inkább a szorongó kötődés volt rájuk jellemző (Gilbert \& Irons, 2008).

Az önkritikus gondolatok, hiedelmek és attribúciók számos pszichopatológia kialakulásában, illetve fennmaradásában szerepet játszanak (Chang, 2008), mint például a depresszió (pl. Blatt, Rounsaville, Eyre, \& Wilber, 1984), az evészavarok (pl. Kelly \& Carter, 2013), az alexitímia (az érzelmek felismerésének képtelensége/hiánya; Gilbert és mtsai, 2011) vagy akár az opiátfüggőség (Blatt és mtsai, 1984).

Gilbert, Clarke, Hempel, Miles és Irons (2004) kutatásának eredménye szerint az önkritikusság minden formája és fajtája együtt jár a depresszióval, különösen amelyik az ént veszélyezteti, és hatására az egyén kárt szándékozik tenni önmagában. Ennek egy lehetséges magyarázata, hogy ha másoktól folyamatosan éles kritikát hallunk, akkor nagyobb eséllyel alakul ki depresszív hangulat, amely hatást pedig a saját gondolataink és képzeteink is ugyanúgy képesek elérni (Gilbert, 2009). Miközben a depressziós emberek igyekeznek minél inkább elkerülni mások kritikáját, a saját magukra vetített önkritikájuk csak növekszik. A Csökkentértékúség/Szégyen és a Könyörtelen mércék/Hiperkritikusság maladaptív sémákkal rendelkező személyek számára nehézséget jelent, hogy elégedettek legyenek a teljesítményükkel, lazítsanak, vagy épp örömet leljenek az életben (Young, Klosko, \& Weishaar, 2003). Továbbá a nagyon magas önkritikával rendelkező személyeknek nehézséget jelent explorációs, vagyis élménykereső viselkedéseket tanúsítani, különösen a pozitív jellegúeket (Gilbert és mtsai, 2004).

A témával kapcsolatos kutatások során azonban azt találták, hogy az önkritikusság nem csak maladaptív formát ölthet. Gilbert és munkatársai 
(2004) különbséget tesznek az önkritikusság különböző formái között: elkülönítik a viselkedést javító és ösztönző, építő jellegú szerepet, valamint a szelf-et csak gyötrő és bántani akaró funkciókat. Vizsgálatuk során arra az eredményre jutottak, hogy az önkritikusság két tényezőből épül fel: egyrészt a hibáinkon való folyamatos rágódásból, és az alkalmatlanság érzéséből, másrészt az önmagunk iránt érzett megvetésből, önutálatból, amely akár azt a szintet is elérheti, hogy ártani is akarjunk magunknak. Ebből adódóan az önkritikusság funkciója is kettős: az első esetben ismertetett része vezethet egy önfejlesztő, önkorrekciós múködéshez, míg a másik inkább egy önbántalmazó, önzaklató szerepet eredményezhet, amely során az egyén a hibái miatt árt önmagának (Gilbert és mtsai, 2004). Whelton és Greenberg (2005) egy csapat egyetemistát figyeltek meg, hogy ezúton tanulmányozzák az önkritikusság folyamatát és hatását az egyénre. A diákokat alacsony és magas önkritikussággal jellemezhető csoportokra osztották, majd egy olyan múltbeli helyzet felidézését kérték tőlük, ahol kudarcot éltek át. Arra voltak kíváncsiak, hogy milyen mértékú önkritikát váltott ki belőlük ennek a korábbi szituációnak a felidézése, illetve hogyan reagáltak az önkritikára. Eredményeik alapján arra jutottak, hogy az önkritikusnak számító csoport tagjai nagyobb beleéléssel fejezték ki önkritikus gondolataikat és kisebb rezilienciával reagáltak a kritikára, valamint sokkal több szégyent és szomorúságot éltek meg. Ezen kívül kevésbé tudták elválasztani magukat a belső kritikájuktól, és nehezükre esett határozott, magabiztos, vagy dühös választ adniuk arra. Érdekesség továbbá, hogy magas önkritika mellett a szívritmus-variabilitás emelkedett értékeit találták, ami a félelemre adott válasz egyik mutatója (Rockliff, Gilbert, McEwan, Lightman, \& Glover, 2008).

Az önkritikusság többfunkciós megközelítéséhez kapcsolódik Chang (2008) elmélete is, aki egy személyiségdimenzióként mutatja be a jelenséget, amelynek kontinuuma mind a pozitív, mind a negatív végleteket tartalmazza. Az önkritikusság tehát lehet inspiráló, megerősítő jellegü, amely segítséget nyújt a céljaink elérésében, és általa kialakulhat az emberben egy kohezív, reális énkép. A másik oldalon azonban egészségtelen és destruktív formát is ölthet, frusztrációt és csüggedtséget hagyva maga után.

\section{1. Önkritikusság és perfekcionizmus}

A diszpozicionális perfekcionizmus olyan általános tendencia a személyiség múködésében, amely a tökéletességre való törekvést és/vagy a személy saját magával kapcsolatos túlzott elvárásait foglalja magában (Flett \& Hewitt, 2002). Akárcsak az önkritikusságnak, a perfekcionizmusnak is lé- 
tezik adaptív és maladaptív formája. Az elóbbi a magas elvárások, egyéni célok megvalósításához közelít, segít „hozni a megszokott színvonalat” (personal standards perfectionism), az utóbbi pedig az önkritikus perfekcionizmus (self-critical perfectionism), amely által az egyén sosem elégedett, és folyamatosan ellenőrzi, értékeli önmagát (Dunkley, Zuroff, \& Blankstein, 2003). Fontos megjegyezni, hogy amíg az adaptív perfekcionizmus közelebb viszi az egyént a céljaihoz, addig az önkritikusság erős hátráltató tényező tud lenni, amely halogatásban és ruminációban nyilvánul meg (Powers, Koestner, \& Zuroff, 2007). Az önkritikus perfekcionisták több negatív és kevesebb pozitív érzést tapasztalnak, mivel sokkal érzékenyebbek a kudarccal fenyegető helyzetekre, stresszorokra (Dunkley és mtsai, 2003). Grzegorek (2002, id. Chang, 2008) megfogalmazása szerint a perfekcionisták akkor sem elégedettek a teljesítményükkel, ha az objektív mutatók által is elismerésre méltó lenne. Mivel a perfekcionizmus szorosan összefügg a depresszióval és az önkritikussággal is (Dunkley és mtsai, 2003; Powers, Zuroff, \& Topciu, 2004), érthető, hogy ez a múködésmód kísértetiesen egybevág a fentebb említett önkritikus depressziós emberek kapcsán leírtakkal (Young és mtsai, 2003, id. Chang, 2008).

\section{2. Önkritikusság és szégyen}

A szégyen egy olyan negatív érzés, amely magában foglalja a tehetetlenséget, a kisebbrendúség-érzést, és a saját hiányosságaink elrejtésének vágyát (Gilbert \& Allan, 1994). Gilbert és Allan (1994) szerint mindez agresszív, dühös vagy önalávetó reakcióhoz egyaránt vezethet. Nathanson (1992, id. Vizin \& Unoka, 2015) érvelése szerint a fentieken túl reagálhat valaki önmaga ellen irányuló agresszióval, elkerüléssel, illetve szerabúzussal is. A szégyenérzet, ami akkor alakul ki, ha a személyt mások kritizálják, elítélik és negatívan látják (külső szégyen), képes elindítani az egyénben egy olyan folyamatot, amely során internalizálja a kívülről kapott negatív ítéleteket (belső szégyen). Mindez egy belső, önmaga ellen irányuló ellenséges viselkedéshez vezethet, ami nem más, mint az önkritika (Gilbert, 1998, 2000, id. Xavier, Gouneia, \& Cunha, 2016). Gilbert és munkatársai (2008) modelljében ilyen értelemben az önkritikusság nem más, mint erre a belső, internalizált szégyenre adott válaszreakció.

A kritikus, elhanyagoló és elutasító szülői bánásmód a depresszió, illetve egyéb internalizáló zavarok kialakulásában is szerepet játszik, amelyben kimutatták az önkritikusság, mint közvetítő változó szerepét (Gilbert és mtsai, 2006). Ez különösen érvényes volt a döntően verbális gyermekkori bántalmazás esetében (Sachs-Ericsson, Verona, Joiner, \& Preacher, 2006). 
Mint láthatjuk, az önkritikusság egy összetett folyamat, amely különböző formákban, különböző helyzetekben és funkciókkal jelenik meg, eltérő érzelmekkel társulva (Gilbert, 2009; Gilbert és mtsai, 2004). Gyakran csalódottság és félelem kíséri, az agyunk pedig fenyegetésként észleli, ezért aktiválja az egyik stresszhormon, a kortizol termelését. Stresszhatásként megélve pedig az önkritikusság a boldogság és a pszichológiai jóllét komoly akadálya lehet. Egyike a leginkább romboló belső emberi folyamatoknak, különösen szégyenérzettel párosulva (Gilbert, 2009).

A szégyen önmagában is negatívan befolyásolja az élet sok területét, és nemcsak önkritikussághoz és komoly gátlásokhoz vezethet, de általa az ember támadólag saját maga ellen is fordulhat. Ez utóbbi jelenség és a szégyenalapú önkritikusság napjainkban a nyugati kultúrák legelterjedtebb problémái közé tartozik, amely aláássa pszichológiai jóllétet és a megelégedettséget (Gilbert, 2009). Ha egy erősen önkritikus embernek rosszul mennek a dolgai, inkább dühös, csalódott és frusztrált lesz, sőt megveti saját magát, mintsem, hogy támogatóan, melegséggel fordulna önmaga felé - így az önegyüttérzés szöges ellentétét testesíti meg (Gilbert, 2009), mint azt a következő részben is bemutatjuk. A szégyen és az önkritikusság pedig nemcsak kölcsönösen felerősítik egymást, de több olyan pszichopatológiai tünettel is összefüggést mutatnak, mint például a depresszió, a szorongás, valamint a stressz okozta tünetek (Castilho, Pinto-Gouveia, \& Duarte, 2017). Kelly és Carter (2013) kutatási eredményei alapján az evészavarok (anorexia nervosa, bulimia nervosa, nem meghatározott evészavar) esetében is komoly súlyosbító tényezőnek számítanak.

\subsection{Együttérzéstől való félelem és önkritikusság}

Maga az együttérzés sokféle módon definiálható: jelentheti a szimpatizálásra való késztetést, motivációt a másokkal való törődésre, egyfajta képességet a kellemetlen érzések tolerálására, empatikus megértésre anélkül, hogy az ítélkezéssel társulna (Gilbert \& Procter, 2006). Goetz, Keltner és SimonThomas (2010) több magyarázat alapján, összességében azt a definíciót hozták létre, hogy az együttérzés egy olyan érzés, ami akkor keletkezik, ha valakit szenvedni látunk, felkeltve bennünk annak vágyát, hogy mihamarabb segítsünk. Az együttérzésnek három fajtáját különítették el a kutatók: (a) a másokkal való együttérzést, (b) a másoktól kapott együttérzést és (c) az önmagunk felé irányuló együttérzést, más néven önegyüttérzést (Gilbert, 2009; Neff, 2003a, 2003b). Együttérzőnek lenni önmagunkkal szemben anynyit tesz, mint nyitottnak lenni a saját szenvedésünk iránt. Az önegyüttérzés magába foglalja, hogy ítélkezés nélkül megértőek vagyunk önmagunk 
fájdalmával, hiányosságaival és bukásaival szemben, azokat általános emberi tapasztalatként fogjuk fel (Neff, 2003a). Így az önegyüttérzés segíti a pszichológiai rugalmasságot (rezilienciát), az érzelmi stabilitást, továbbá alacsonyabb mértékú én-felnagyítást és ego-védekezést tesz szükségessé, ezáltal képes csökkenteni az alkalmatlanság érzéséből keletkező negatív érzelmeket (Sági, Köteles, \& V. Komlósi, 2013). Kutatásokban kimutatták, hogy az együttérzéstől való félelem (fóképp a másoktól kapott, és az önegyüttérzéstől való félelem) szorosan összefügg az önmegnyugtatással, mindfulness-szel és a biztonságérzettel kapcsolatos nehézségekkel, valamint az alexitímiával és az önkritikussággal (Gilbert és mtsai, 2012).

Sok ember számára az együttérzés gyengeséget jelent, kibújást a felelősség alól, vagy akár veszélyes is lehet, hogy valaki lebontja a maga köré épített falakat. Másoknál az együttérzésre szorongásos érzelmi válasz kondicionálódott, annak következményeként, hogy a múltban nyitottak voltak egy személy gondoskodása iránt, de az a fontos személy bántalmazóvá vagy elutasítóvá vált (Gilbert \& Procter, 2006).

Mindezen tapasztalatok alapján az együttérzéstől való félelem mérésére Gilbert és munkatársai (2011) létrehozták a Fears of Compassion Scales (Együttérzéstől való Félelem Skálák) elnevezésú kérdőívet. A kérdőív az együttérzés három fajtáját foglalja magában, úgymint 1. másoktól kapott együttérzés, 2. mások iránti együttérzés, valamint 3. önmagunkkal szembeni kedvesség és együttérzés (önegyüttérzés). Ezen dimenziók másik végletén az ezektől való félelem szerepel. Mivel az önegyüttérzésnek része a magunkkal szembeni kedvesség, ami szemben áll az önkritikával (Neff, 2003b), érthető válik, hogy az önutálat és az elégtelenség érzése pozitív irányú kapcsolatban áll az önegyüttérzéstől való félelemmel, illetve a másoktól kapott együttérzéstől való félelemmel (Gilbert és mtsai, 2011). Hasonló eredményre jutottak Gilbert és munkatársai egy 2012-es kutatásban, amikor pozitív irányú, közepes mértékú korrelációt fedeztek fel az önegyüttérzéstől való félelem, a boldogságtól való félelem és az önkritikusság között (elégtelenség érzése, önutálat), illetve mérsékelt erősségú, negatív irányú korrelációt az önegyüttérzéstől való félelem, a boldogságtól való félelem és az önmegerősítés között.

Az önegyüttérzés negatívan kapcsolódik az önkritikussághoz (Neff, 2003a), amely összefüggést alátámasztja az is, hogy az egyik mód ennek a „belső kínzásnak” a legyőzésére egy együttérző megnyilvánulás kialakítása önmagunk felé (Gilbert \& Procter, 2006). Neff (2003a, 2009) nemi különbségeket is felfedezett a kutatásaiban, ami abban nyilvánult meg, hogy a nók szignifikánsan alacsonyabb eredményt mutattak az önegyüttérzés és a mindfulness terén, míg az önítélkezés, az izoláció és a túlzott azonosulás terén szignifikánsan magasabb eredményt értek el, mint a férfiak. Későbbi ku- 
tatásaiban azonban Neff (2007a, 2007b) nem talált szignifikáns különbséget a nemek között, habár a minta túlnyomó részét mindkét esetben nók képezték (68\% és 95\%). Egy másik kutatásban (Neff \& McGehee, 2010), ahol serdülőket vizsgáltak, szintén nem mutatkozott szignifikáns nemi különbség az önegyüttérzés terén.

A szégyen, az önutálat és az önegyüttérzéstől való félelem közvetetten előre vetíti a nem-szuicidális önsértést (Non suicidal self injury; NSSI) a serdülőknél. Ráadásul, az önkritikusság legpatológiásabb formája, az önutálat, szorosan összefügg az NSSI-vel (Xavier és mtsai, 2016). A nemi különbségeket vizsgálva itt azonban jelentős eltérés mutatkozott: a serdülő lányok magasabb szégyenérzetet, önkritikát (önutálatot), önegyüttérzéstól való félelmet és depresszív tüneteket mutattak, mint a fiú társaik.

\subsection{Az önkritikusság mérése}

Hazánkban eddig még nem adaptáltak és nem is fejlesztettek ki az önkritikusság mérésére szolgáló mérőeszközt, ezzel szemben külföldön már több megbízható tesztet is alkalmaznak a kutatók (Blatt, Quinlan, Chevron, McDonald, \& Zuroff, 1982; Falconer, King, \& Brewin, 2015; Gilbert és mtsai, 2004; Thomphson \& Zuroff, 2004). Leghamarabb a Depressive Experiences Questionnaire (DEQ) született meg, amely bár a depresszióhoz kapcsolódó tapasztalatokat méri, mégis tartalmaz az önkritikusságot méró tételeket is (Blatt, D'Afflitti, \& Quinlan, 1976, id. Blatt és mtsai, 1982). A DEQ ezekből álló alskáláját napjainkig előszeretettel alkalmazzák a különböző kutatásokban (pl. Blatt és mtsai, 1982; Michaeli, Hakhnigari, Dickson, Scharf, \& Shulman, 2019; Powers, Koestner, \& Zuroff, 2007).

2004-ben három másik önkritikusságot mérő skála is napvilágot látott, a Levels of Self-Criticism Scale (LOSC; Thompson \& Zuroff, 2004), a Functions of Self-Criticizing/Attacking Scale (FSCS; Gilbert és mtsai, 2004) és a Forms of Self-Criticizing/Attacking and Self-Reassuring Scale (FSCRS; Gilbert és mtsai, 2004). A LOSC két alskálán méri az önkritikusság szintjeit - a komparatív (Comparative Self-Criticism) és az internalizált (Internalized Self-Criticism) önkritikusságot (Thompson és Zuroff, 2004). Az FSCS pedig az önkritikusság lehetséges okait és funkcióit vizsgálja (Gilbert és mtsai, 2004).

A legfrissebb, 2015-ben született mérőeszköz a Self-Compassion and SelfCriticism Scales (SCCS), amely az önegyüttérzés és az önkritikusság dimenzióit hivatott mérni. Érdekessége, hogy az előzőekkel ellentétben nem egyszerú állításokat kell értékelnie a kitöltónek, hanem azt, hogy különböző, az én-t fenyegető helyzetben hogyan viszonyulna önmagához (Falconer, King, \& Brewin, 2015). 


\subsection{Az Önkritikusság és Önmegerősítés Skála}

A jelen kutatás központjában álló, fent említett Forms of Self-Criticizing/ Attacking and Self-Reassuring Scale (FSCRS; magyarul Önkritikusság és Önmegerősítés Skála; FSCRS-HU) egyszerre vizsgálja az önkritikusság két formáját, valamint ezek ellentétét, az önmegerősítést, illetve az önmegnyugtató képességet. Az önkritikusság egyik fajtája itt az alkalmatlanság, elégtelenség érzésére vonatkozik, amelyet nehézségek vagy kudarc esetén érez az ember, pl. „Egy részem úgy érzi, hogy nem vagyok elég jó”, s ez alapján az alskála is "alkalmatlan én” (inadequate self) elnevezést kapta. A másik forma már sokkal rombolóbb jelenség: undor, ellenszenv és önutálat keveredik benne, sőt az egyén agresszív késztetést is érezhet arra, hogy egy-egy kudarcot követően kárt tegyen magában, pl. „Annyi düh halmozódott fel bennem, hogy legszívesebben kárt tennék magamban". Az erre vonatkozó alskála a "gyúlölt én" (hated self) elnevezést kapta. Végül a harmadik skála, a "megerősített én" (reassured self), az egyén pozitívumait emeli ki, amikor az egyén gondoskodik magáról, bátorítja és támogatja önmagát, még ha rosszul is alakulnak a dolgok, pl. „Képes vagyok emlékeztetni magamat a pozitívumaimra" (Gilbert és mtsai, 2004).

A kérdőív konfirmatív faktorelemzése és validálása után is a háromfaktoros modell bizonyult a legmegfelelőbbnek. Ugyanezen vizsgálatban nemek közti különbségeket is megfigyeltek. A nők szignifikánsan magasabb pontszámokat értek el az alkalmatlan én, és szignifikánsan alacsonyabb pontszámokat a megerósített én alskálán, mint a férfiak (Kupeli, Chilcot, Schmidt, Campbell, \& Troop, 2013). Továbbá a teszt alkotói (Gilbert és mtsai, 2004) megjegyzik, hogy az életkor is enyhe, de szignifikáns befolyásoló tényezóként jelenik meg - a fiataloknál magasabb értékeket figyelhetünk meg a gyülölt én alskálán, egyelőre tisztázatlan okokból.

Castilho és munkatársai (2017) hangsúlyozzák, hogy az önkritikusság két formáját, az alkalmatlan én-t és a gyülölt én-t fontos külön kezelni és vizsgálni, hiszen más mintázatokban és más patológiákhoz társulva jelennek meg. Az önegyüttérzéstől való félelemmel és a boldogságtól való félelemmel azonban mindkét forma pozitív irányú együttjárást mutatott (Gilbert és mtsai, 2012), mint ahogyan a depresszióval is - amivel viszont a megerósített én negatív irányú kapcsolatban áll (Mills, Gilbert, Bellew, McEwan, \& Gale, 2007).

Az FSCRS skálával végzett kutatások során többek között azt is megállapították, hogy a túlzott önkritika könnyen patológiás formába csaphat át, és szoros összefüggésben áll a depresszióval (Gilbert és mtsai, 2004). Az önkritikusság legpatológiásabb formája pedig akár önsértéssel is együtt járhat (Xavier és mtsai, 2016). 


\section{A vizsgálat célja}

Jelen kutatás célja a Gilbert és munkatársai (2004) által kidolgozott Forms of Self-Criticizing/Attacking and Self-Reassuring Scale magyar változatának validitás- és reliabilitásvizsgálata. A kutatás a Károli Gáspár Református Egyetem (KRE) Pszichológiai Intézetének keretein belül zajlott 2018 szeptemberétól. A kutatást a KRE Pszichológiai Intézetének Etikai Bizottsága hagyta jóvá (az engedély száma: 403/2018/P). A kutatás vezetóje Dr. Szabó-Bartha Anett volt, aki egy nagyobb, keresztmetszeti vizsgálat keretein belül vizsgálta a pozitív érzelmektól való félelem összefüggéseit egyéb változókkal, így többek között az önkritikussággal. A kutatás célja ezen összefüggések feltárása mellett a Magyarországon eddig még kevésbé ismert és magyar nyelven nem elérhető kérdőívek validálása volt (pl. Együttérzéstól való Félelem Skálák, Boldogságtól való Félelem Skála).

Jelen tanulmányunkban az Önkritikusság és Önmegerősítés Skála validálási folyamatának bemutatását és a legfóbb eredmények ismertetését túztük ki célul. A 3 alskálával rendelkező kérdőív esetében magyar mintán a következőket feltételeztük:

1. Az Önkritikusság és Önmegerősítés Skála elméleti faktorstruktúrája a magyar mintán is megjelenik.

2. Az Önkritikusság és Önmegerősítés Skála alskáláinak belső megbízhatósága megfelelő (Cronbach- $\alpha>0,7$ ).

3. Az Önkritikusság és Önmegerősítés Skála két alskálája (alkalmatlan én, gyúlölt én) pozitív irányú, lineáris, egy alskálája (megerősített én) pedig negatív irányú, lineáris összefüggést mutat a depresszióval.

4. Az Önkritikusság és Önmegerősítés Skála két alskálája (alkalmatlan én, gyúlölt én) negatív irányú lineáris, egy alskálája (megerősített én) pedig pozitív irányú, lineáris összefüggést mutat az élettel való elégedettséggel.

5. Az Önkritikusság és Önmegerősítés Skála két alskálája (alkalmatlan én, gyưlölt én) pozitív irányú lineáris, egy alskálája (megerősített én) pedig negatív irányú lineáris összefüggést mutat az önegyüttérzéstől való félelemmel.

\section{Módszerek}

\subsection{Vizsgálati minta és eljárás}

A 2018 szeptemberében induló keresztmetszeti kutatás során a pozitív érzelmektől való félelem önkritikussággal és társas összehasonlítással való kapcsolatát vizsgáltuk. Ennek részeként került lefolytatásra a jelen tanulmányban bemutatásra kerülő Önkritikusság és Önmegerősítés Skála 
validálása. Első lépésként a KRE Pszichológiai Intézete oktatóinak és hallgatóinak bevonásával került sor a kérdőív angolról magyarra történő fordítására, miután arra engedélyt kértünk a skála megalkotójától, Dr. Paul Gilberttől. A magyar fordítás angolra történő visszafordítására két külső szakembert kértünk fel, akik nyelvhelyességi ellenőrzést és tartalmi/jelentésbeli elemzést is végeztek a magyar nyelvű változat kapcsán. Az angol nyelvưre visszafordított verziót Dr. Paul Gilberttel közösen egyeztetve véglegesítettük és finomítottuk a magyar változat fordítását. A kérdőív végsó verziója a Függelékben található.

A kérdőívcsomag terjesztése, illetve felvétele a Károli Gáspár Református Egyetem III. éves BA és V. éves MA pszichológia szakos hallgatók bevonásával történt. A vizsgálati személyeket hólabda módszerrel, elsősorban internetes közösségi felületeken (pl. Facebook és más közösségi oldalak) keresztül, illetve e-mailek küldésével gyújtöttük össze (336fő), 100 fő adatait pedig papíralapú kitöltés során vettük fel (azon személyek esetében, akik online nem voltak elérhetőek, vagy nehézséget jelentett a számukra a technikai eszközök használata). A kutatásban való részvétel önkéntes alapon zajlott. Az online és papíralapú kitöltésre kerülő kérdőívcsomag elején tájékoztatott beleegyezést kértünk a résztvevőktől, amelyben elismerték, hogy biztosítottuk őket adataik anonimitásáról, személyük beazonosíthatatlanságáról, valamint a kutatás megszakításának feltétel nélküli lehetóségéről, és a vizsgálat céljáról is átfogó képet kaptak. Beválasztási kritérium volt, hogy a kitöltó életkora legalább betöltött 18 év legyen, felső életkori határt nem húztunk meg, továbbá, hogy a mentális egészség tekintetében a sine morbo csoportba tartozzon.

A vizsgálatban így összesen 436 fő vett részt, 2 főt azonban ki kellett zárni az alacsony életkora miatt, így 434 fő maradt: 107 férfi és 327 nő. A minta 18 és 73 év közötti magyar felnőttekből áll, az átlagéletkoruk 30,2 (SD = 12,15) év.

A kitöltők közel fele (45\%) egyedülálló, 24\%-a párkapcsolatban, 14\%-a élettársi kapcsolatban, 17\%-a pedig házasságban él. A válaszadók többségének (76\%) nincs gyermeke, 8\%-nak egy, 10\%-nak kettő, 3\%-nak három és 1\%-nak négy, illetve egy kitöltőnek 6 gyermeke van. A legmagasabb iskolai végzettség alapján a minta nagyrészt érettségizett (46,5\%), illetve diplomás (47\%) emberekből áll. A PhD-vel rendelkezők (2\%), a csak általános iskolát végzettek (2\%) és a szakképzettséggel rendelkezők (2,5\%) aránya igen alacsony. Vallásosság tekintetében pedig a többség (62\%) a maga módján vallásos (azaz hívőnek tartja magát, de a vallását rendszeresen nem gyakorolja), 23\% ateista, és a maradék 15\% vallásosnak tartja magát. 


\subsection{Mérőeszközök}

Az Önkritikusság és Önmegerősités Skála (Forms of Self-Criticizing/Attacking and Self-Reassuring Scale; FSCRS; Gilbert és mtsai, 2004) egy 22 tételes önbeszámoló kérdőív, amelyben azt értékelik a kitöltők, hogy hogyan gondolkodnak, illetve reagálnak arra, amikor rosszul mennek a dolgaik. Mindegyik tétel úgy kezdődik, hogy „Amikor rosszul mennek a dolgaim...”, és az ezt követó állításokat kell egy 5-fokozatú Likert-típusú skálán értékelnie a kitöltóknek az egyáltalán nem értek egyet (0) és a teljesen egyetértek (4) végpontok között. Három alskálából áll, úgymint alkalmatlan én (pl. „Képtelen vagyok elfogadni a kudarcokat és a csalódásokat anélkül, hogy ne érezzem magam alkalmatlannak”), gyülölt én (pl. „Undorodom magamtól”), és megerősített én (pl. „Mindenek dacára úgy szeretem magam, amilyen vagyok"). Az alskálákon elért magasabb pontszámok az alkalmatlanság, az önutálat és az önmegerósítés magasabb szintjére utalnak. Az eredeti kérdőív belső konzisztenciája jó: a gyülölt én és a megerősített én alskálákhoz tartozó Cronbach- $\alpha$-érték mindkét esetben 0,86, az alkalmatlan én alskála Cronbach- $\alpha$-értéke pedig 0,90 (Gilbert és mtsai, 2004).

A DASS-21, az eredeti 42 itemes Depresszió és Szorongás Kérdőív (Depression, Anxiety and Stress Scale; DASS; Lovibond \& Lovibond, 1995) rövidített változata. Ez az önkitöltő kérdőív egészséges és klinikai mintán is egyaránt megbízhatóan méri a depresszió, a szorongás, illetve a stressz dimenzióit. Jelen kutatásban csak a 7 tételes depresszió alskálát alkalmaztuk. A válaszadók egy 4-fokozatú Likert-típusú skálán - az egyáltalán nem volt rám jellemző (0) és az igen tekintélyes mértékben vagy a nagyon gyakran jellemző volt rám (3) végpontok között - értékelik, hogy az elmúlt hét során mennyire voltak rájuk jellemzőek a depresszió egyes tünetei. A magasabb pontszám magasabb szintú depressziót jelez. A kérdőív érvényessége megfelelő, a belső konzisztenciája jó (Szabó, 2010). A 21 tételes változat nemcsak rövidebb, de letisztultabb faktorstruktúrával is rendelkezik, kisebb faktorok közötti korrelációval, ami miatt elónyösebb is a használata a DASS-42-vel szemben (Antony, Bieling, Cox, Enns, \& Swinson, 1998). A mérőeszköz hazai adaptálása folyamatban van a Debreceni Egyetem Orvos- és Egészségtudományi Centrum Népegészségügyi Karán Dr. Kósa Karolina vezetésével. A kérdőív magyar változatát az ő engedélyével használtuk fel.

Az Élettel való Elégedettség Skála (Satisfaction With Life Scale; SWLS; Diener, Emmons, Larsen, Griffin, 1985; magyar változat: Martos, Sallay, Désfalvi, Szabó, \& Ittzés, 2014) egy öt tételből álló, globális elégedettséget vizsgáló kérdőív, amely az egyik leggyakrabban használt szubjektív jólléttel kapcsolatos mérőeszköz. A kérdőív egyes tételeit 7-fokú Likert-típusú skálán az egyáltalán nem értek egyet (1) és a teljes mértékben egyetértek (7) végpontok között értékeli a kitöltő, aszerint, hogy milyen mértékben ért 
egyet az adott állításokkal. A skálán elért magasabb pontszám az élettel való elégedettség magasabb szintjét jelzi. A magyar változat pszichometriai mutatói megfelelóek, a skála strukturális validitása és belső konzisztenciája kiváló (Martos és mtsai, 2014).

Az Együttérzéstől való Félelem Skálák (Fear of Compassion Scales, FCS; Gilbert és mtsai, 2014) elnevezésú kérdőív egyaránt méri a mások iránti együttérzést, a másoktól kapott kedvességet és együttérzést, valamint az önmagunk iránti kedvességet és együttérzést - tehát az együttérzés különböző dimenzióit. Az alskálák 13, 15, illetve 17 itemet tartalmaznak, az elóbb említett sorrendben. A válaszadóknak egy 5-fokozatú Likert-típusú skálán az egyáltalán nem értek egyet (0) és a teljes mértékben egyetértek (4) végpontok között kell megjelölniük, hogy az adott állítás mennyire tükrözi a véleményüket. Az alskálákon elért magasabb pontszám magasabb szintú együttérzésre utal. A mérőeszköz pszichometriai mutatói megfelelőek, amelyek alapján megbízhatónak és érvényesnek bizonyul (Gilbert és mtsai, 2011). Az Együttérzéstól való Félelem Skálák magyar változatának faktorstruktúrája az eredetihez hasonló kialakításúnak, megbízhatósága és konvergens validitása megfelelőnek bizonyult. A mérőeszköz a boldogságtól való félelemmel, a depresszió-, szorongás-, és stressz-szinttel szignifikáns, közepesen erós, pozitív korrelációt mutatott (Szabó-Bartha, Szombathelyi, \& Takács, megjelenés alatt). Jelen kutatásban az önmagunk iránti kedvesség és együttérzés alskálájával dolgoztunk.

\subsection{Statisztikai elemzések}

A skálák belső megbízhatóságát Cronbach- $\alpha$-mutató számításával becsültük meg. A feltáró faktorelemzést Maximum Likelihood módszerrel és Direct Oblimin rotációval végeztük, majd Unweighted Least Squares módszerrel ellenöriztük, illetve megerösitó faktorelemzést is alkalmaztunk azért, mert a normalitás egyes változók esetében sérült (1. táblázat). Az illeszkedési mutatók közül a következőket vettük figyelembe: RMSEA, SRMR, TLI és CFI indexek (Takács, 2020). Az egyes alskálák közti korrelációkat, illetve azoknak az életkorral és más kérdőívek alskáláival való együttjárását Spearman-féle rangkorrelációs elemzéssel vizsgáltuk, a nemi különbségeket pedig MannWhitney-féle U-próbával. A nemi különbségek hatásmértékének becslésére rang Cohen- $d$-mutatót számítottunk. 
Az adatok elemzése az IBM SPSS Statistics 23, valamint RopStat 2.0 statisztikai programmal történt. A konfirmatív faktoranalízis lefolytatásához a JASP programot ${ }^{1}$ használtuk.

\section{Eredmények}

Az 1. táblázatban a kutatás során használt legfontosabb összehasonlító skálák leíró statisztikai adatait foglaltuk össze, amelyek megbízhatósága megfelelőnek bizonyult a jelen mintán is.

1. táblázat. A felhasznált skálák leíró adatai és belső megbízhatósága

\begin{tabular}{|l|c|c|c|c|c|}
\hline \multicolumn{1}{|c|}{ Skálák } & Átlag & SD & Cronbach- $\alpha$ & Ferdeség & Csúcsosság \\
\hline $\begin{array}{l}\text { Önmagunk iránti kedvesség } \\
\text { és együttérzés (FCS) }\end{array}$ & 17,18 & 13,80 & 0,94 & $0,905^{* * *}$ & 0,317 \\
\hline Depresszió (DASS-21) & 6,16 & 5,87 & 0,92 & $0,881^{* * *}$ & $-0,384$ \\
\hline $\begin{array}{l}\text { Élettel való elégedettség } \\
\text { (SWLS) }\end{array}$ & 22,23 & 6,63 & 0,86 & $-0,292^{*}$ & $0,668^{* *}$ \\
\hline
\end{tabular}

Megjegyzés: * $p<0,5 ;{ }^{* *} p<0,01 ;{ }^{* * *} p<0,001$.

\subsection{Faktorelemzés}

A konfirmatív faktorelemzés a következő eredményeket hozta. Az illeszkedési mutatók közül a hibákat méró RMSEA és SRMR mutatók az alábbiakat mutatták: a kérdőív négyzetes közelítés hibája a megengedett 0,06 alatti (RMSEA $=0,056)$, valamint a standardizált reziduális négyzetes hiba (SRMR $=0,044$ ) is az elfogadható tartományban helyezkedik el, 0,08 alatt (Takács, 2020). Az illeszkedési indexek vizsgálata során a Tucker-Lewis-index (TLI) kissé elmarad az elvárt 0,95-ös értéktől $(0,930)$, az összehasonlító illeszkedési mutató (CFI) azonban meghaladja $(0,945)$ az elvárt 0,9-es értéket. Mindezek alapján elmondható, hogy alapvetően elfogadható az adatok illeszkedése a háromfaktoros elméleti modellre, de hogy bizonyosságot nyerjünk az itemek elrendeződését illetően, mind Maximum Likelihood, mind pedig

1 https://cran.r-project.org/web/packages/lavaan/citation.html 
Unweighted Least Squares módszerrel ellenőriztük az eljárásunkat, hogy a megerősítő faktorelemzésben ellenőrzött elrendeződést mutatják-e a feltáró faktormodell eredményei is.

Az Önkritikusság és Önmegerősítés Skála feltáró faktorelemzése során a Maximum Likelihood eljárást alkalmaztuk Direct Oblimin rotációval, mivel az egyes faktorok között lineáris összefüggést feltételezünk. Az elemzés illeszkedési mutatója (Kaiser-Meyer-Olkin-mutató; KMO = 0,947) megfelelő, és a Bartlett-féle szfericitásteszt is szignifikáns $\left(\chi^{2}(231)=4760,071 ; p<0,001\right)$ volt, amely eredmények egy kiváló faktorstruktúra kialakításának lehetőségére utaltak. A kommunalitások azonban két item (4. és 18.) esetén nem érték el a minimum 0,25-ös értéket. A 18. item („,Megérdemlem az önkritikáimat") kommunalitása volt a legalacsonyabb $(0,103)$, és a faktorstruktúrához is csak gyengén illeszkedett (a faktorsúlya 0,28 volt), ezért a további számításokból ezt az itemet már kihagytuk.

A KMO-mutató értéke $(0,948)$ és a Bartlett-teszt eredménye $\left(\chi^{2}(210)=\right.$ $4687,651 ; p<0,001)$ továbbra is kiváló elóre jelzó értékekkel szolgált. A kommunalitásoknál immáron csak egy tétel nem érte el a minimálisan elvárt 0,25-ös értéket, de mivel a faktorstruktúrába elfogadhatóan illeszkedett (a faktorsúlya 0,454 volt), ezért ezt a tételt meghagytuk. A háromfaktoros modell magyarázó (varianciahányad) ereje meghaladja a minimálisan elvárt $50 \%$-ot $(51,2 \%)$.

A feltáró faktorelemzésünk eredménye majdnem teljes egészében visszatükrözi a kérdőív eredeti struktúráját, egyedül a 15. tétel („Gyakran pocskondiázom magam”) került a gyülölt én helyett az alkalmatlan én alskálára. Az eredményeket a 2. táblázat szemlélteti. Mind a Maximum Likelihood, mind pedig az Unweighted Least Square módszer azonos eredményt hozott a faktorstruktúrát illetően - természetesen némileg eltérő súlyokkal, de azonos faktorra rendeződés mellett. Az elrendeződésnél nem a faktorsúlyok 2-es szorzótényezőjét vettük figyelembe (Székelyi \& Barna, 2002), hanem 1,5-ös szorzót, ugyanis a megerósító faktorelemzés szintén ezt az elrendeződést támasztotta alá.

Ezzel megerősítést nyert számunkra, hogy mind a konfirmatív elemzés, mind két különböző feltáró faktor modell az itemek azonos elrendezését eredményezte, tehát a skáláinkat stabilnak gondoljuk ( $p<0,05$ szignifikanciaszint mellett vizsgáltuk a faktorelemzés eredményeit, mindkét módszernél mindkét forgatást alkalmazva).

A Spearman-féle rangkorrelációs elemzés eredménye szerint közepes mértékú kapcsolat mutatkozik az alskálák között. Az alkalmatlan én és a megerösített én negatívan, az alkalmatlan én és a gyülölt én pozitívan, valamint a megerősitett én és a gyülölt én szintén negatívan jár együtt. Ezeket az eredményeket a 2. táblázat foglalja össze. 
2. táblázat. Az Önkritikusság és Önmegerősítés Skála feltáró faktorelemzésének eredményei és az alskálák egymással való korrelációja, valamint leíró adatai

\begin{tabular}{|c|c|c|c|c|}
\hline Sorszám & Az itemek tartalma & Alkalmatlan én & Megerósített én & Gyúlölt én \\
\hline 2 & $\begin{array}{l}\text { Van egy részem, ami } \\
\text { mindig lehúz engem. }\end{array}$ & 0,821 & $-0,514$ & 0,475 \\
\hline 6 & $\begin{array}{l}\text { Egy részem úgy érzi, } \\
\text { hogy nem vagyok } \\
\text { elég jó. }\end{array}$ & 0,801 & $-0,516$ & 0,446 \\
\hline 7 & $\begin{array}{l}\text { Lehangolnak az } \\
\text { önkritikus } \\
\text { gondolataim. }\end{array}$ & 0,770 & $-0,445$ & 0,443 \\
\hline 1 & $\begin{array}{l}\text { Könnyen csalódok } \\
\text { magamban. }\end{array}$ & 0,768 & $-0,559$ & 0,532 \\
\hline 15 & $\begin{array}{l}\text { Gyakran } \\
\text { pocskondiázom } \\
\text { magam. }\end{array}$ & 0,723 & $-0,537$ & 0,563 \\
\hline 17 & $\begin{array}{l}\text { Képtelen vagyok } \\
\text { elfogadni } \\
\text { a kudarcokat és } \\
\text { csalódásokat anélkül, } \\
\text { hogy ne érezzem } \\
\text { magam } \\
\text { alkalmatlannak. }\end{array}$ & 0,689 & $-0,517$ & 0,459 \\
\hline 14 & $\begin{array}{l}\text { Emlékszem a } \\
\text { kudarcaimra és } \\
\text { hajlamos vagyok } \\
\text { rágódni azokon. }\end{array}$ & 0,681 & $-0,438$ & 0,346 \\
\hline 20 & $\begin{array}{l}\text { Van egy olyan } \\
\text { oldalam, ami szeretne } \\
\text { megszabadulni } \\
\text { azoktól a részeimtől, } \\
\text { amiket nem szeretek. }\end{array}$ & 0,649 & $-0,454$ & 0,405 \\
\hline 4 & $\begin{array}{l}\text { Nehezen tudom } \\
\text { kezelni a dühömet és } \\
\text { a frusztrációmat. }\end{array}$ & 0,453 & $-0,342$ & 0,378 \\
\hline 11 & $\begin{array}{l}\text { Mindent összevetve } \\
\text { szerethetónek és } \\
\text { elfogadhatónak } \\
\text { érzem magamat. }\end{array}$ & $-0,524$ & 0,784 & $-0,552$ \\
\hline 16 & $\begin{array}{l}\text { Gyengéd és támogató } \\
\text { vagyok magammal } \\
\text { szemben. }\end{array}$ & $-0,513$ & 0,752 & $-0,322$ \\
\hline
\end{tabular}




\begin{tabular}{|c|c|c|c|c|}
\hline Sorszám & Az itemek tartalma & Alkalmatlan én & Megerősített én & Gyúlölt én \\
\hline 8 & $\begin{array}{l}\text { Mindenek dacára } \\
\text { olyannak szeretem } \\
\text { magam, amilyen } \\
\text { vagyok. }\end{array}$ & $-0,407$ & 0,730 & $-0,387$ \\
\hline 13 & $\begin{array}{l}\text { Nem esik nehezemre, } \\
\text { hogy kedveljem } \\
\text { magam. }\end{array}$ & $-0,433$ & 0,671 & $-0,388$ \\
\hline 21 & $\begin{array}{l}\text { Bátorítom magam a } \\
\text { jövőt illetően. }\end{array}$ & $-0,448$ & 0,661 & $-0,393$ \\
\hline 3 & $\begin{array}{l}\text { Képes vagyok } \\
\text { emlékeztetni } \\
\text { magamat a } \\
\text { pozitívumaimra. }\end{array}$ & $-0,399$ & 0,611 & $-0,301$ \\
\hline 19 & $\begin{array}{l}\text { Képes vagyok } \\
\text { magamra vigyázni és } \\
\text { törődni magammal. }\end{array}$ & $-0,447$ & 0,604 & $-0,364$ \\
\hline 5 & $\begin{array}{l}\text { Könnyen meg tudok } \\
\text { bocsátani magamnak. }\end{array}$ & $-0,457$ & 0,552 & $-0,275$ \\
\hline 10 & $\begin{array}{l}\text { Undorodom } \\
\text { magamtól. }\end{array}$ & 0,566 & $-0,548$ & 0,866 \\
\hline 9 & $\begin{array}{l}\text { Annyi düh } \\
\text { halmozódott fel } \\
\text { bennem, hogy } \\
\text { legszívesebben kárt } \\
\text { tennék magamban. }\end{array}$ & 0,558 & $-0,478$ & 0,825 \\
\hline 12 & $\begin{array}{l}\text { Már nem törődöm } \\
\text { magammal. }\end{array}$ & 0,428 & $-0,426$ & 0,615 \\
\hline 22 & $\begin{array}{l}\text { Nem szeretek } \\
\text { önmagam lenni. }\end{array}$ & 0,534 & 0,532 & 0,610 \\
\hline \multicolumn{5}{|c|}{ Korrelációs együtthatók } \\
\hline Alkalmatlan én & 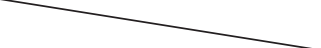 & & $-0,64^{* * *}$ & $0,67^{* * *}$ \\
\hline Megerósített én & 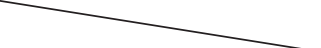 & & & $-0,56^{* * *}$ \\
\hline \multicolumn{5}{|l|}{ Leíró adatok } \\
\hline Átlag & & 19,60 & 21,11 & 2,86 \\
\hline Szórás & 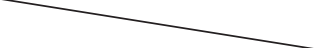 & 8,60 & 6,01 & 3,36 \\
\hline Cronbach- $\alpha$ & & 0,90 & 0,87 & 0,83 \\
\hline Ferdeség & P & $-0,095$ & $-0,405^{* * *}$ & $1,229^{* * *}$ \\
\hline Csúcsosság & & $-0,596^{*}$ & $-0,096$ & $1,275^{* * *}$ \\
\hline
\end{tabular}

Megjegyzés: Maximum Likelihood módszer Direct Oblimin rotációval. A faktorsúlyok szignifikanciaszintje: $p<0,05$; $p<0,5$; ${ }^{* * *} p<0,001$. 


\subsection{Reliabilitás}

Az egyes alskálák Cronbach- $\alpha$-mutatói magas értékeket vettek fel, ami erős belsó konzisztenciára utal, tehát mind az „alkalmatlan én” $(0,90)$, mind a „megerósített én” $(0,87)$, mind pedig a "gyúlölt én” $(0,83)$ alskála megbízhatónak bizonyul. A vizsgált skálák standard értékeit, normalitási mutatóit és Cronbach- $\alpha$-értékeit a 2. táblázat szemlélteti.

\subsection{Validitás}

Mivel a ferdeségi és csúcsossági mutatók alapján (1-2. táblázat) sérül a változók normális eloszlása, az együttjárásokat Spearman-féle rangkorrelációs elemzéssel vizsgáltuk. Az életkor egyedül az alkalmatlan én alskálával mutat közepes mértékư, szignifikáns, negatív irányú együttjárást, a másik két alskála (megerősített én és gyúlölt én) esetében csak gyenge, bár szignifikáns összefüggések figyelhetők meg.

Az alkalmatlan én szignifikánsan, pozitív irányban, közepes erősséggel együttjár mind az önegyüttérzéstől való félelemmel, mind a depresszióval, valamint fordítottan az élettel való elégedettséggel is. A megerősitett én esetén szintén szignifikáns, közepes erősségú együttjárást találunk, ám itt az élettel való elégedettséggel pozitív, az együttérzéstől való félelemmel és a depresszióval pedig negatív irányú ez a kapcsolat. Végül a gyülölt én esetében is szignifikáns és közepes mértékú együttjárásokat figyelhetünk meg, amely az alkalmatlan én alskálához hasonlóan az önegyüttérzéstől való félelemmel és a depresszióval pozitív, az élettel való elégedettséggel pedig negatív irányú. Az eredményeket a 3. táblázat szemlélteti.

3. táblázat. A változók közötti együttjárások

(Spearman-féle rangkorrelációs együtthatók)

\begin{tabular}{|l|c|c|c|c|}
\hline $\begin{array}{c}\text { Az Önkritikusság } \\
\text { és Önmegerósítés } \\
\text { Skála alskálái }\end{array}$ & Életkor & $\begin{array}{c}\text { Önmagunk iránti } \\
\text { kedvesség és } \\
\text { együttérzés (FCS) }\end{array}$ & $\begin{array}{c}\text { Depresszió } \\
\text { (DASS-21) }\end{array}$ & $\begin{array}{c}\text { Élettel való } \\
\text { elégedettség } \\
\text { (SWLS) }\end{array}$ \\
\hline Alkalmatlan én ${ }^{1}$ & $-0,39^{* *}$ & $0,65^{* *}$ & $0,68^{* *}$ & $-0,51^{* *}$ \\
\hline Megerősített én & $0,20^{* *}$ & $-0,51^{* *}$ & $-0,61^{* *}$ & $0,60^{* *}$ \\
\hline Gyúlölt én & $-0,24^{* *}$ & $0,68^{* *}$ & $0,62^{* *}$ & $-0,52^{* *}$ \\
\hline
\end{tabular}

Megjegyzés: ${ }^{1}=$ a 18. tétel kihagyásával; ${ }^{* *} p<0,01$. 
Az esetleges nemi különbségeket a normalitás sérülése miatt MannWhitney-féle $U$-próbával vizsgáltuk az egyes alskálák mentén. A próba egyedül az alkalmatlan én alskála esetében jelzett (alacsony hatásmérték mellett) szignifikáns eltérést a rangátlagok közt $(Z=-2,109 ; p=0,040$; rang Cohen- $d=-0,229)$, amint azt a 4 . táblázat szemlélteti.

4. táblázat. Nemi különbségek az Önkritikusság és Önmegerősítés Skála alskálái mentén

\begin{tabular}{|l|c|c|c|c|}
\hline $\begin{array}{c}\text { Az Önkritikusság és } \\
\text { Önmegerósítés Skála } \\
\text { alskálái }\end{array}$ & $\begin{array}{c}\text { Férfiak } \\
(n=107) \\
\text { átlag }\end{array}$ & $\begin{array}{c}\text { Nók } \\
(n=327) \\
\text { átlag }\end{array}$ & $Z$ & $\begin{array}{c}\text { Rang } \\
\text { Cohen- } \boldsymbol{d}\end{array}$ \\
\hline Alkalmatlan én ${ }^{1}$ & $\begin{array}{c}17,94 \\
(\mathrm{SD}=8,54)\end{array}$ & $\begin{array}{c}20,14 \\
(\mathrm{SD}=8,57)\end{array}$ & $-2,109^{*}$ & $-0,229$ \\
\hline Megerősített én & $\begin{array}{c}20,89 \\
(\mathrm{SD}=5,79)\end{array}$ & $\begin{array}{c}21,19 \\
(\mathrm{SD}=6,09)\end{array}$ & $-0,416$ & $-0,046$ \\
\hline Gyúlölt én & $\begin{array}{c}2,785 \\
(\mathrm{SD}=2,84)\end{array}$ & $\begin{array}{c}2,89 \\
(\mathrm{SD}=3,52)\end{array}$ & 0,149 & 0,017 \\
\hline
\end{tabular}

Megjegyzés: ${ }^{1}=$ a 18. tétel kihagyásával; ${ }^{*} p<0,05$.

\section{Megbeszélés}

Keresztmetszeti, kérdőíves, hozzáférhetőségi mintavételt alkalmazó kutatásunkban a Forms of Self-Criticizing/Attacking and Self-Reassuring Scale (FSCRS; Gilbert és mtsai, 2004) magyar nyelvre adaptálását, valamint validálás- és reliabilitásvizsgálatát végeztük el hazai mintán.

Első hipotézisünk, amely az Önkritikusság és Önmegerősítés Skála (FSCRS-HU) háromfaktoros elméleti faktorstruktúrájára vonatkozott, beigazolódott. A megerősító és feltáró faktoranalíziseink eredményei alapján magyar mintán is kirajzolódik a háromfaktoros elméleti modell, akárcsak az eredeti kérdőív (Gilbert és mtsai, 2004) esetében. A 22 itemból azonban egyet (18.) sajnos el kellett vetni az alacsony kommunalitása miatt, és mert a kialakult faktorokhoz is csak gyengén kapcsolódott. Érdekes, hogy a teszt kifejlesztésekor éppen ez a tétel („Megérdemlem az önkritikáimat”) számított a legerősebbnek az alkalmatlan én alskálán (Gilbert és mtsai, 2004), itt pedig a leggyengébbnek - az egész skálát tekintve is. Ennek lehetnek nyelvi okai, de akár a minta összetétele (többségben a fiatal felnőtt nők) eredményezhetett ilyen eltérő eredményt. 
A faktorelemzés eredményeképpen még egy tétel esetében tapasztaltunk eltérést a várthoz képest, mert az eredeti kérdőívhez képest másik alskálára került. A 15. tétel („Gyakran pocskondiázom magam”) a jelen mintán a gyülölt én alskála helyett az alkalmatlan én alskálán foglal helyet.

Az Önkritikusság és Önmegerősítés Skála mindhárom alskálája (a 18. tétel kihagyásával) erős belső konzisztenciát mutatott, így a teszt megbízhatóságára vonatkozó második hipotézisünk is beigazolódott.

Végül az Önkritikusság és Önmegerősítés Skála validitásával kapcsolatos hipotéziseink is alátámasztást nyertek, megerősítve a korábbi kutatások eredményeit. A depresszió és az önkritikusság kapcsolatát már sokan vizsgálták (pl. Blatt és mtsai, 1984; Castilho és mtsai, 2017; Gilbert és mtsai, 2004). Jelen kutatásunkban is szignifikáns, pozitív irányú együttjárást találtunk az alkalmatlan én, a gyülölt én és a depresszió közt, valamint szignifikáns, negatív irányú együttjárást a megerősített én és a depresszió közt, akárcsak Mills és munkatársai (2007). Tehát az önkritikusságra való fokozott hajlam magasabb szintú depresszióval jár együtt.

Az önegyüttérzéstől való félelem esetében is az előbbiekhez hasonló eredményeket kaptunk. Gilbert és munkatársai (2012) kutatása alapján az alkalmatlan én és a gyülölt én pozitív irányban, a megerösitett én pedig negatív irányban jár együtt az önegyüttérzéstől való félelemmel, amely összefüggések magyar mintán is tisztán kirajzolódtak. Ez alapján, aki önkritikusabb, az jobban fél az önmagával való együttérzéstól.

Az önkritikusság és az élettel való elégedettség közvetlen kapcsolatáról nem találtunk szakirodalmat, azonban az önkritikusságnak a perfekcionizmussal való összefüggése miatt mégis összefüggést feltételeztünk, mivel a perfekcionisták rendszerint nem elégedettek, még akkor sem, ha a teljesítményük objektív mutatók által is elismerésre méltó lenne (Grzegorek, 2002; id. Chang, 2008). Továbbá kevés pozitívumot és sokkal több negatívumot érzékelnek, mivel különösen kiélezettek a kudarcra (Dunkley és mtsai, 2003). Kutatásunk alapján e hipotézis is megerősítést nyert. Míg a megerősített én pozitívan, addig az alkalmatlan én és a gyülölt én negatívan korrelált az élettel való elégedettséggel, tehát a magasabb önkritikussághoz alacsonyabb élettel való elégedettség társul.

A Kupeli és munkatársai (2013) által megfigyelt nemi különbségek egy részét is sikerült tetten érni a hazai mintán. Az alkalmatlan én alskálán szignifikánsan magasabb pontszámokat értek el a nők, mint a férfiak. A másik két alskála esetében azonban nem mutatkozott szignifikáns különbség. Itt is feltételezhető, hogy kulturális hatások, nyelvi okok, vagy a mintavétel módja állhat a háttérben és érdemes lenne további vizsgálatokat végezni erre vonatkozóan. 
Az Önkritikusság és Önmegerősítés Skála kidolgozói (Gilbert és mtsai, 2004) a gyülölt én alskála esetében az életkor enyhe, de szignifikáns befolyásoló erejéról is beszámolnak. Jelen mintán mindhárom alskála esetében megfigyelhető ez a gyenge, de szignifikáns, sőt, az alkalmatlan én esetében már közepesnek mondható hatás. Úgy túnik, hogy a fiatalabb korosztály alkalmatlanabbnak érzi magát az idősebb korosztályhoz képest. Ennek okai szintén tisztázatlanok és feltárásra várnak.

\section{A kutatás korlátai és kitekintés}

A kutatás limitációi között említhetjük, hogy kényelmi (de nagyobb esetszámú) mintavétel történt, ami korlátozhatja a kérdőív specifikus csoportokon való alkalmazhatóságát. Továbbá ki kell emelnünk a minta reprezentativitásának korlátait: ennek eltolódása figyelhető meg a fiatal felnőtt korosztály, illetve a női nem irányába, így a következtetések levonásánál ezt érdemes figyelembe venni.

A kutatás kiegészítéseként megemlíthető, hogy a konkurens validitás szempontjából érdemes lett volna a mérőeszközöket kiegészíteni további olyan eszközökkel, amelyek az általunk validált skálához hasonló konstruktumot mérnek. Ilyen mérőeszköz lehet az Önegyüttérzés Skála (SelfCompassion Scale) Önbírálat alskálája (Sági, Köteles, \& Komlósi, 2013), illetve az Önkritikus Rumináció Skála (Self-Critical Rumination), amely az önkritikus gondolatokon való rágódás és rumináció konstruktumát méri (Smart, Peters, \& Baer, 2016).

Összességében az Önkritikusság és Önmegerősítés Skála magyar nyelvú változata megbízhatónak és érvényesnek bizonyult. Ennek köszönhetóen hazánkban is megkezdődhet az önkritikusságra való hajlam alaposabb vizsgálata. Remélhetőleg több hasonló kérdőív adaptálására is sor kerül a közeljövôben, hiszen az önkritikussággal való foglalkozás önismereti szempontból is lényegesnek tekinthető és eredményeink nem csak a szakemberek számára lehetnek mérvadóak. Az önkritikusságra való hajlam alakulásának hátterében álló szülői nevelői attitúdök ismerete az elsődleges prevenció szempontjából kiemelkedő, míg az önkritikusság különböző pszichopatológiai állapotokkal, illetve az önegyüttérzéssel és a pszichológiai jólléttel mutatott összefüggéseinek ismerete révén a szekunder és tercier prevenciós folyamatokban is fontos szerepet játszhat. 


\section{Irodalom}

Antony, M.M., Bieling, P.J., Cox, B.J., Enns, M.W., \& Swinson, R.P. (1998). Psychometric properties of the 42-item and 21-item versions of the Depression Anxiety Stress Scales in clinical groups and a community sample. Psychological Assessment, 10(2), 176-181.

Blatt, S.J., Quinlan, D.M., Chevron, E.S., McDonald, C., \& Zuroff, D. (1982). Dependency and self-criticism: psychological dimensions of depression. Journal of Consulting and Clinical Psychology, 50(1), 113-124.

Blatt, S.J., Rounsaville, B., Eyre, S.L., \& Wilber, C. (1984). The psychodynamics of opiate addiction. Journal of Nervous and Mental Disease, 172(6), 342-352.

Castilho, P., Pinto-Gouveia, J., \& Duarte, J. (2017). Two forms of self-criticism mediate differently the shame-psychopathological symptoms link. Psychology and Psychotherapy: Theory, Research and Practice, 90(1), 44-54.

Chang, E.C. (2008). Self-criticism and self-enhancement: Theory, research, and clinical implications. Washington, DC: American Psychological Association

Diener, E., Emmons, R.A., Larsen, R.J., \& Griffin, S. (1985). The Satisfaction With Life Scale. Journal of Personality Assessment, 49(1), 71-75.

Dunkley, D.M., Zuroff, D.C., \& Blankstein, K.R. (2003). Self-critical perfectionism and daily affect: Dispositional and situational influences on stress and coping. Journal of Personality and Social Psychology, 84(1), 234.

Flett, G.L., \& Hewitt, P.L. (2002). Perfectionism and maladjustment: An overview of theoretical, definitional, and treatment issues. In P.L. Hewitt, \& G.L. Flett (Eds.), Perfectionism: Theory, research, and treatment (5-31). Washington, DC: American Psychological Association

Gilbert, P. (1998). What is shame? Some core issues and controversies. In P. Gilbert \& B. Andrews (Eds.), Shame: Interpersonal behaviour, psychopathology and culture (3-36). New York, NY: Oxford University Press

Gilbert, P. (2000). Social mentalities: Internal 'social' conflicts and the role of inner warmth and compassion in cognitive therapy. In P. Gilbert \& K. G. Bailey (Eds.), Genes on the couch: Explorations in evolutionary psychotherapy (pp. 118-150). Hove: Psychology Press

Gilbert, P. (2009). The compassionate mind: A new approach to life's challenges. Oakland, CA: New Harbinger Publications

Gilbert, P., Baldwin, M.W., Irons, C., Baccus, J.R., \& Palmer, M. (2006). Self-criticism and self-warmth: An imagery study exploring their relation to depression. Journal of Cognitive Psychotherapy, 20(2), 183-200.

Gilbert, P., Clarke, M., Hempel, S., Miles, J.N., \& Irons, C. (2004). Criticizing and reassuring oneself: An exploration of forms, styles and reasons in female students. British Journal of Clinical Psychology, 43(1), 31-50.

Gilbert, P., \& Irons, C. (2008). Shame, self-criticism, and self-compassion in adolescence. In N. Allen, \& L. Sheeber (Eds.), Adolescent emotional development and the emergence of depressive disorders (195-214). New York, NY: Cambridge University Press

Gilbert, P., McEwan, K., Gibbons, L., Chotai, S., Duarte, J., \& Matos, M. (2012). Fears of compassion and happiness in relation to alexithymia, mindfulness, and self-criticism. Psychology and Psychotherapy: Theory, Research and Practice, 85(4), 374-390.

Gilbert, P., McEwan, K., Matos, M., \& Rivis, A. (2011). Fears of compassion: Development of three self-report measures. Psychology and Psychotherapy, 84(3), 239-255.

Gilbert, P., Pehl, J., \& Allan, S. (1994). The phenomenology of shame and guilt: An empirical investigation. British Journal of Medical Psychology, 67(1), 23-36. 
Gilbert, P., \& Procter, S. (2006). Compassionate mind training for people with high shame and self-criticism: Overview and pilot study of a group therapy approach. Clinical Psychology and Psychotherapy, 13(6), 353-379.

Goetz, J.L., Keltner, D., \& Simon-Thomas, E. (2010). Compassion: An evolutionary analysis and empirical review. Psychological Bulletin, 136(3), 351-374.

Grzegorek, J.L. (2002). Perfectionists' cognitive and affective reactions to self-relevant evaluative feedback. Unpublished doctoral dissertation. State College, PA: Pennsylvania State University

Kelly, A.C., \& Carter, J.C. (2013). Why self-critical patients present with more severe eating disorder pathology: The mediating role of shame. British Journal of Clinical Psychology, 52(2), 148-161.

Kupeli, N., Chilcot, J., Schmidt, U.H., Campbell, I.C., \& Troop, N.A. (2013). A confirmatory factor analysis and validation of the forms of self-criticism/reassurance scale. British Journal of Clinical Psychology, 52(1), 12-25.

Lovibond, P.F., \& Lovibond, S.H. (1995). The structure of negative emotional states: Comparison of the Depression Anxiety Stress Scales (DASS) with the Beck Depression and Anxiety Inventories. Behaviour Research and Therapy, 33(3), 335-343.

Martos, T., Sallay, V., Désfalvi, J., Szabó, T., \& Ittzés, A. (2014). Az Élettel való Elégedettség Skála magyar változatának (SWLS-H) pszichometriai jellemzői. Mentálhigiéné és Pszichoszomatika, 15(3), 289-303.

Michaeli, Y., Hakhmigari, M.K., Dickson, D.J., Scharf, M., \& Shulman, S. (2019). The role of change in self-criticism across young adulthood in explaining developmental outcomes and psychological wellbeing. Journal of Personality, 87(4), 785-798.

Nathanson, D.L. (1992): Shame and pride: Affect, sex, and the birth of the self. New York: W.W. Norton \& Co.

Neff, K.D. (2011): Self-compassion, self-esteem and well-being. Social and Personality Psychology Compass, 5(1), 1-12.

Neff, K.D., \& Mcgehee, P. (2010). Self-compassion and psychological resilience among adolescents and young adults. Self and Identity, 9, 37-41.

Powers, T.A., Koestner, R., \& Zuroff, D.C. (2007). Self-criticism, goal motivation, and goal progress. Journal of Social and Clinical Psychology, 26(7), 826-840.

Powers, T.A., Zuroff, D.C., \& Topciu, R.A. (2004). Covert and overt expressions of selfcriticism and perfectionism and their relation to depression. European Journal of Personality, 18(1), 61-72.

Rosseel, Y. (2012). lavaan: An R Package for Structural Equation Modeling. Journal of Statistical Software, 48(2), 1-36.

Sachs-Ericsson, N., Verona, E., Joiner, T., \& Preacher, K.J. (2006). Parental verbal abuse and the mediating role of self-criticism in adult internalizing disorders. Journal of Affective Disorders, 93(1-3), 71-78.

Sági, A., Köteles, F., \& V. Komlósi, A. (2013). Az Önmagunk Iránt Érzett Együttérzés (Önegyüttérzés) skála magyar változatának pszichometriai jellemzói. Pszichológia, 33(4), 293-312.

Smart, L.M., Peters, J.R., \& Baer, R.A. (2016). Development and validation of a measure of self-critical rumination. Assessment, 23(3), $321-332$.

Szabó, M. (2010). The short version of the Depression Anxiety Stress Scales (DASS-21): Factor structure in a young adolescent sample. Journal of Adolescence, 33(1), 1-8.

Szabó-Bartha, A., Szombathelyi, R., \& Takács, Sz. (megjelenés alatt): Az Együttérzéstól való Félelem Skála validálása. Psychologia Hungarica Caroliensis. 
Székelyi M., Barna I. (2002). Túlélőkészlet az SPSS-hez. Többváltozós elemzési technikákról társadalomkutatók számára. Budapest: Typotex Kiadó

Takács, Sz. (2020). Bevezetés a matematikai statisztikába, elmélet és gyakorlat, 3. kötet. Budapest: Antarész Kiadó

Vizin, G., \& Unoka, Zs. (2015). A szégyen szerepe a mentális zavarok kialakulásában II. Szégyen mérése és a szégyen kapcsolata a mentális zavarokkal. Psychiatria Hungarica, 30, 278-296.

Whelton, W.J., \& Greenberg, L.S. (2005). Emotion in self-criticism. Personality and Individual Differences, 38(7), 1583-1595.

Xavier, A., Gouveia, J.P., \& Cunha, M. (2016). Non-suicidal self-injury in adolescence: The role of shame, self-criticism and fear of self-compassion. Child and Youth Care Forum, 45(4), 571-586.

Young, J.E., Klosko, J.S., \& Weishaar, M.E. (2003). Schema therapy: A practitioner's guide. New York, NY: Guilford Press

\section{Köszönetnyilvánítás}

A szerzók a tanulmány alapjául szolgáló kutatást a Személyiség- és Egészségpszichológiai Kutatómúhely 20655B800 témaszámú, a Károli Gáspár Református Egyetem Bölcsészet- és Társadalomtudományi Kara által finanszírozott pályázat keretében végezték.

\section{Szerzói munkamegosztás}

Borostyánkői Zsófia: szakirodalmi összefoglalás, az adatok feldolgozása. Takács Szabolcs: statisztikai feldolgozás. Szabó-Bartha Anett: a kutatás vezetője, a cikk szövegének javítása, kiegészítése.

\section{Nyilatkozat érdekütközésról}

A szerzők ezúton kijelentik, hogy esetükben nem állnak fenn érdekütközések. 


\section{Függelék: Önkritikusság és Önmegerôsítés Skála}

Amikor a dolgok rosszul mennek az életünkben, vagy nem úgy alakulnak, ahogy szeretnénk, sokféle gondolat és érzés felmerülhet bennünk. Az alábbiakban ilyen önmagunkkal kapcsolatos állításokat olvashat. Kérjük, minden állításnál karikázza be azt a számot, ami a leginkább jellemző Önre!

0 = Egyáltalán nem értek egyet

$1=$ Nem értek egyet

2 = Semleges, vagy nem tudom

3 = Egyetértek

$4=$ Teljesen egyetértek

Amikor a dolgaim rosszul alakulnak:

\begin{tabular}{|l|l|l|l|l|l|}
\hline Könnyen csalódom magamban. & 0 & 1 & 2 & 3 & 4 \\
\hline Van egy részem, ami mindig lehúz engem. & 0 & 1 & 2 & 3 & 4 \\
\hline Képes vagyok emlékeztetni magamat a pozitívumaimra. & 0 & 1 & 2 & 3 & 4 \\
\hline Nehezen tudom kezelni a dühömet és frusztrációmat. & 0 & 1 & 2 & 3 & 4 \\
\hline Könnyen meg tudok bocsátani magamnak. & 0 & 1 & 2 & 3 & 4 \\
\hline Egy részem úgy érzi, hogy nem vagyok elég jó. & 0 & 1 & 2 & 3 & 4 \\
\hline Lehangolnak az önkritikus gondolataim. & 0 & 1 & 2 & 3 & 4 \\
\hline Mindenek dacára olyannak szeretem magam, amilyen vagyok. & 0 & 1 & 2 & 3 & 4 \\
\hline $\begin{array}{l}\text { Annyi düh halmozódott fel bennem, hogy legszívesebben kárt } \\
\text { tennék magamban. }\end{array}$ & 0 & 1 & 2 & 3 & 4 \\
\hline Undorodom magamtól. & 0 & 1 & 2 & 3 & 4 \\
\hline Mindent összevetve szerethetónek és elfogadhatónak érzem magam. & 0 & 1 & 2 & 3 & 4 \\
\hline Már nem töródöm magammal. & 0 & 1 & 2 & 3 & 4 \\
\hline Nem esik nehezemre, hogy kedveljem magam. & 0 & 1 & 2 & 3 & 4 \\
\hline Emlékszem a kudarcaimra és hajlamos vagyok rágódni azokon. & 0 & 1 & 2 & 3 & 4 \\
\hline Gyakran pocskondiázom magam. & 0 & 1 & 2 & 3 & 4 \\
\hline Gyengéd és támogató vagyok magammal szemben. & 0 & 1 & 2 & 3 & 4 \\
\hline $\begin{array}{l}\text { Képtelen vagyok elfogadni a kudarcokat és csalódásokat anélkül, } \\
\text { hogy ne érezzem magam alkalmatlannak. }\end{array}$ & 0 & 1 & 2 & 3 & 4 \\
\hline Képes vagyok magamra vigyázni és törődni magammal. & 0 & 1 & 2 & 3 & 4 \\
\hline $\begin{array}{l}\text { Van egy olyan oldalam, ami szeretne megszabadulni azoktól } \\
\text { a részeimtól, amiket nem szeretek. }\end{array}$ & 0 & 1 & 2 & 3 & 4 \\
\hline Bátorítom magam a jövót illetően. & 0 & 1 & 2 & 3 & 4 \\
\hline Nem szeretek önmagam lenni. & 0 & 1 & 2 & 3 & 4 \\
\hline
\end{tabular}




\title{
Skálaképzési útmutató:
}

A kérdőív nem tartalmaz fordított tételt, azonban a Megerősített én alskála (tartalmilag) ellentétes a másik kettővel, ezért nem számoljuk összesítve a 3 alskála értékeit.

A skálaképzés a hozzájuk tartozó tételek összeadásával történik.

Alkalmatlan én alskála: 1., 2., 4., 6., 7., 14., 15., 17. és 19. tétel

Megerősitett én alskála: 3., 5., 8., 11., 13., 16., 18. és 20. tétel

Gyưlölt én alskála: 9., 10., 12. és 21. tétel

\section{Hungarian validation of the Self-Criticizing/Attacking and Self-Reassuring Scale}

\author{
BOROSTYÁNKÖI, ZSÓFIA - TAKÁCS, SZABOLCS - \\ SZABÓ-BARTHA, ANETT
}

Background: Due to the Hungarian version of the Self-Criticizing/Attacking and SelfReassuring Scale, the phenomenon of self-criticism has become measurable in Hungary as well. Aims: In the present study we present the applicability of the Self-Criticism and SelfReassuring Scale on a Hungarian sample and its relationship to depression, life satisfaction, and fear of self-compassion. Methods: A total of 434 people participated in the research: 107 men and 327 women, with a mean age of $30.2(S D=12.15)$ years. Results: The exploratory factor analysis indicated a three-factor structure similar to the original version of the SelfCriticism and Self- Reassuring Scale, the Hungarian sample also showed the dimensions of the inadequate self, the reassured self and the hated self. This structure was also confirmed by confirmatory factor analysis $(\mathrm{RMSEA}=0.056, \mathrm{CFI}=0.945)$ and the internal reliability of the subscales proved to be adequate (Cronbach's $\alpha=0.9,0.87$, and 0.83 , respectively). The FSCRS-HU showed a significant, moderate association with both depression $(r=0.62-0.68 ; p<0.01)$ and fear of self-compassion $(r=0.65-0.68, p<0.01)$ and life satisfaction $(r=[-0.51]-[-0.52], p=0.01)$. Age had a weak and, in the case of an inadequate self, a moderately significant effect on all three subscales. There was a significant difference between the sexes only in the case of the inadequate self $(Z=-2.109, p=0.040$, rank Cohen's $d=-0.229)$. Conclusions: Overall, the Self-Criticism and Self- Reassuring Scale proved to be a reliable and valid measurement tool in the Hungarian sample as well.

Keywords: Self-Criticizing/Attacking and Self-Reassuring Scale (FSCRS), self-criticism, self-reassurement, depression, fear of self-compassion, life satisfaction, validity

\footnotetext{
A cikk a Creative Commons Attribution 4.0 International License (https:/ / creativecommons.org/ licenses/by/4.0/) feltételei szerint publikált Open Access közlemény, melynek szellemében a cikk bármilyen médiumban szabadon felhasználható, megosztható és újraközölhető, feltéve, hogy az eredeti szerző és a közlés helye, illetve a CC License linkje és az esetlegesen végrehajtott módosítások feltüntetésre kerülnek. (SID_1)
} 